\title{
Rodríguez González, Félix. 2011. Diccionario del sexo y el erotismo. Alianza Editorial: Madrid. 1150 pp.
}

\author{
Reviewed by Martín Jamieson
}

Buenos Aires

Criticism often levelled at dictionaries of many languages includes the fact that fourletter words and similar expressions referring to taboo items are kept off their pages. Due to this, specialized dictionaries focusing on such excluded material have been compiled, sometimes in school-boy fashion, as the dirty work of the smirking child who learns the power of prohibited words and scurrilously shares them, and other times as the scientific oeuvre of those who consider it necessary to register the full scope of language in society.

Félix Rodríguez González"s new dictionary, Diccionario del sexo y el erotismo, is of the latter type. It follows in the path hewn out by Camilo José Cela"s two-volume Diccionario secreto which appeared with Spain"s return to democracy and its destape of the 70s. (During those years and shortly after, publishers in Spain rushed to circulate "forbidden" texts written by classical writers of previous centuries until then considered prudish and straitlaced). On going through the Diccionario del sexo y el erotismo, no one would think of claiming that Rodríguez González"s dictionary is the result of wanting to ride a wave of anti-prudery or of aspiring to capitalize in wallowing in talk about "beastly acts" or perversions. (Puto el que lee. Diccionario argentino de insultos, injurias e improperios, Revista Barcelona, Buenos Aires, 2006, for instance, would seem to be in the latter league.) Rodríguez"s is a scientific proposal that is of use to either the layman or the erudite observer. Whoever needs to be updated on contemporary Peninsular sexual beliefs, slang and practices can turn to this book and be rapidly appraised. (Dictionaries, it is needless to note, are not only linguistic items, but storehouses of social experience.)

Félix Rodríguez González is a Spanish professor who has taught and researched at the University of Alicante for more than three decades as well as a lexicographer of note who has been studiously compiling dictionaries with a sociolinguistic focus. His Nuevo diccionario de anglicismos (1997), co-authored with Antonio Lillo Buades, records the noticeable influx of English words present in 20th century Peninsular Spanish. His Diccionario de terminología y argot militar: Vocabulario del soldado y la vida del cuartel (2005), and his Diccionario gay-lésbico. Vocabulario general y argot de la homosexualidad (2008) are further proof of his interest in lexicography, and have made him hone his technique in compiling vocabularies and defining terms. He has also completed a Diccionario de la droga: Vocabulario técnico y argot, yet to be published. These books are only part of his work. Rodríguez González has also participated in international projects dealing with the influence of English on other languages, his contributions mainly related to Spanish, and he has also written or edited other papers.

This over thousand-page long Diccionario del sexo y el erotismo focuses primarily on items (the blurb tells of 6200 headings) of contemporary European Spanish although a few forms heard in other Spanish-speaking areas are included. A special effort seems 
to have been made to include the non-hegemonic varieties of Spain, so studies of Canary Islands and Andalusian Spanish form part of its bibliography. (I"ve only been able to pinpoint one work on Spanish from America, a volume by Miguel Ángel Quesada, a Costa Rican who publishes on Central American Spanish and mentors works by others interested in the area.) Rodríguez explicitly declares that "[e]1 diccionario se ha compilado teniendo en cuenta la terminología utilizada en España, y sólo por comparación o contraste aparece citado esporádicamente algún término de uso en Hispanoamérica" (p. 21). He further suggests that his dictionary may "ofrecer algunas pautas de interés para la redacción de diccionarios (o glosarios) semejantes en otras áreas o lenguajes de especialidad, o que se ocupen de la misma temática en otros países de habla española" (p. 24). This has already partially been done, though not as thoroughly as Rodríguez González has, by Manuel Criado de Val"s Diccionario de español equívoco (Madrid, SGEL, 1981), for Spain, and by Sergio Bufano and Jorge Santiago Perednik"s Diccionario de la injuria (Buenos Aires, Losada, 2005), that covers Spanish America, but that is more an insult dictionary than one focused on vocabulary referring to sex and erotism.

A lucid, well-written prologue by the author establishes the characteristics of this dictionary. Its traits can be synthesized as follows: 1 . It is synchronic because it refers to contemporary Spanish, and the mentions of previous stages of the language are used only for clarification. 2. It is syntopic because its area of reference is one country, Spain. 3. It includes written texts of varying register, focusing specially on web-based material, which has powerfully drawn his attention. 4. Everyday language heard on radio, television, on the streets or culled from newspapers and magazines along with material from dictionaries of a similar nature is included; books and erudite research papers are scoured, therefore "el diccionario recoge tanto voces populares o callejeras como puta y beso negro como otras más técnicas, eufemísticas y asépticas, como trabajadora del sexo y anilingus. En ocasiones he incluido comentarios y datos de interés histórico-cultural y filológico que facilitarán su comprensión. Y en ciertos casos, también, otros de carácter enciclopédico, por lo que el diccionario es también, en parte, una enciclopedia del sexo y del erotismo" (p. 20).

Rodríguez González is not only scientific in establishing the origin of his corpus, but also explains how each entry is organized:

Cada entrada consta de una definición, información gramatical (marcas de género y, a veces, de número), y, en ciertos casos, la pronunciación (especialmente en palabras provenientes del inglés). Ocasionalmente, con algunas palabras y expresiones clave, se ofrecen también datos sobre su etimología, su uso estilístico, su frecuencia (o rareza) y su origen y evolución, que serán de interés para el filólogo.

Como novedad interesante, en la medida en que no es una práctica muy seguida en España en las recopilaciones de argot y estudios sobre léxicos especiales, en la mayoría de los casos he incorporado citas de textos que contienen la palabra en cuestión y la fuente documental (en abreviatura) donde se han encontrado. (p. 22) 
Very little can be objected to this pioneering work, since Rodríguez has been meticulous in his declared methodology, research and demeanor, and his book has to be measured by the standards he has established. Delving into pages taken at random leads to saying the following: (1) Certain quotes seem too long, and others do not really seem to be adequately explanatory. (Check the quote for cuarto sexo, for example). (2) Some definitions might be considered a tad off-color. Definitions are expected to be in metalanguage, with slang forms absent. (I recall follar and mariquita among others used in them.) (3) A few may be slightly imprecise: under túnel del amor one finds a mention of "la época pre-gay", which supposes that there is a pre-gay period, a gay one and maybe even a post-gay one, all of which are left without clarification. Also, despite his open-mindedness (without which this dictionary simply would not have existed), and his focus on changing mores in society and in dictionary writing, the author does not seem to be able to escape moralizing ("en este período tardomedieval se produce también una relajación moral ", p. 11, or "una etapa dominada por la liberación de las costumbres y la corrección política”, p. 24; emphasis mine in both cases).

In summing up, this new Diccionario del sexo y del erotismo is a multipurpose one, is a welcome addition to any library holding lexicographical works relating to Spanish and a useful item for those who would study contemporary Spanish society and mores. 
Henry, Gordon D. Jr. Stories Through Theories. Theories Through Stories. North American Indian Writing, Storytelling, and Critique. East Lansing: Michigan State University Press, 2009. 327 pp.

\section{Reviewed by M. Teresa González Mínguez}

Contemporary American Indian writers, literary critics, and scholars have expressed various degrees of "resistance" to Western discourse and theory. However, in different strains of discourse and narrative, American Indian scholars, critics, and writers have embraced, acknowledged, or tended to methodologies and terminology of theory to advance certain intellectual interests and cultural perspectives in their writing. Gordon D. Henry Jr., Nieves Pascual Soler and Silvia Martínez-Falquina began this collection of articles out of a sense that American Indian Literature and the study of such often stands in a contentious yet complicit relationship with Western Eurocentric literary theory. Stories of theories, theories of stories, stories as theories, and theories as stories are presented from a variety of perspectives through many different strategies of discourse by a group of Native and non-Native storytellers and scholars from the U.S., Canada and Spain who explore the ways in which American Indian literature treats theory in the imaginary spaces of fiction, poetry, and drama.

The book, divided into three parts -"Living to Tell," "Critical Traces," "Of Good Listeners-" starts with Gordon Henry"s "Allegories of Engagement: Stories / Theories-A Few Remarks." This introduction deals with the relationships between theory and American Indian works by Gerald Vizenor and other scholars such as Penelope Myrtle Kelsey and Youngblood Henderson. Henry explores the allegories of the deconstructive trickster and the anti-trickster and claims how white colonial scholars have silenced Native voices in the process of interpreting methodological frameworks around Native texts. Above all, he emphasizes the idea that theory, like story, may bring us closer to the impossibilities of reconciling our needs and desires to legitimize our theories through experiences and vice versa.

P. Jane Hafen begins the first part of this volume with "Living To Tell Stories," an essay in which she demonstrates some of the complexities of centering critical approaches within tribal apparatus using several concrete examples. Hafen highlights Gordon Henry"s definition of oppression and colonization as the hallmark of Native American resistance literature, as well as remarks on Choctaw Devon Mihesuah"s observation of responsibility to the community as the most serious problem in Native studies today. She criticizes those scholars who spend their whole careers studying Indian and Indian literatures without ever meeting an American Indian, and praises what she defines as "our allies" (Henry et al 2009: 30)-those who carefully lay foundations of understanding through deliberate scholarship and through awareness of the political implications of their work. Through Laura Tohe"s and Esther Belin"s poems, Hafen"s students see the holistic intricacies and diversity of tribal cultures, and are finally able to recognize the importance of American Indians as part of 
contemporary living cultures as well as the place of American Indian literature in a decolonized context.

In the next essay, Bob Appleford examines the chapter entitled "The Supernatural Stobe Light" in Ray A. Young Bear"s experimental autobiography Black Eagle Child: The Facepaint Narratives, arguing that his story attempts to build a notion of the self around what is a series of unexpected and revelatory "centres," including an uncanny encounter with extraterrestrial visitors. This "humanist model of autobiography" (Henry et al 2009: 47) invites the reader to transform the autobiographer"s Other into a self, deriving pleasure from the process of reading and making another"s life. Edgar Bearchild - the protagonist- has not confessed his sense of failure openly to anyone but the readers, "allowing them to dismiss the reality of the fantastic events Young Bear bears witness" (Henry et al 2009: 53). For Appleford, Bearchild"s experiences present a twofold challenge that involves readers and the protagonist: a challenge to understanding self-discovery, and a challenge to understanding how readers can or wish to undertake this self-discovery.

The modern theoretical problem of the untranslatability of Indian legends is the central topic of Harry Brown"s article. Conscious of the inevitable hermeneutic distortions of ritual stories when translated, Brown argues that "untranslatability represents not a barrier to understanding but rather the liberation of the storyteller to make new meanings from old stories" (Henry et al 2009: 67). Through analyzing the techniques of Zitkala-Sa and Mourning Dove, he demonstrates that translation represents a means of overcoming cultural understanding and racial difference. For Morning Dove, legend is indivisible from language. Zitkala-Sa, on the other hand, separates legend from the Sioux language. For both of them, "the fundamental dilemma was that preserving Native lore required its translation, but in this act of translation, the lore was ultimately lost" (Henry et al 2009: 78-79). However, Brown concludes their hybrid legends are the best solution for intercultural connection and the preservation of an oral culture altered by the white man.

Elvira Pulitano bases her discussion on Gerald Vizenor"s Interior Lanscapes (1990), a blending of autocritiques of everyday writing. She discusses how Vizenor becomes at once both a creator and theorist of the genre of autobiography and explores the ways in which such a text as Interior Landscapes adds to the current discourse of life writing, while interrogating Vizenor"s intriguing ideas on the self in light of his return to the autobiographical motif in his recent poetry. Pulitano defines his work as an example of autocritical writing through which the author continues to wage his cultural word wars on restricted views of mixed blood identity while confirming his dedication to stories and narratives of survival.

Utilizing Ignatia Broker"s Night Flying Woman: An Ojibway Narrative and its characters Oona and Awasasi as models of "lived feminisms," Molly McGlennen examines the shortcomings of Western feminisms" applications to Native American women"s texts by addressing the complexities of what she terms a Native women"s theory. Through Broker"s and other Native women"s words, McGlenenn points out, "we learn that creative expression creates the critical models, models that teach women 
how to heal, how to live in the right way, how to keep in balance" (Henry et al 2009: 117).

The second section opens with Nigonwedom James Sinclair on the important critical and creative contributions of Gerald Vizenor, whose imaginative ideas can be applied to current material struggles of Indigenous (and specifically Anishinaabeg) sovereignty and self-determination. Sinclair argues that Vizenor"s writing is deeply applicable to one of the most important processes happening in Anishinaabeg communities: "the redefining, reestablishment, and reassertion of practices and processes necessary for [their] notions of nationhood to be reactualized" (Henry et al 2009: 128).

While affirming the geocentric boundaries of indigeneity, Susan Berry Brill de Ramírez"s essay suggests ways by which Native American literatures shed light on contemporary theories of diaspora, which, in turn, can open up new directions for critical interpretations and understandings of indigenous literary works. To this aim she uses the poems of Acoma Pueblo poet, scholar and storyteller Simon J. Ortiz, who demonstrates how a late twentieth and early twenty-first century indigenous poetry can provide the means for intercultural communications that can transcend both personal affiliations and the broader public geopolitics of place and nationhood without the erasure of either. A "conversive storytelling," she elucidates, "[is] perhaps the most powerfully integrative means available to assist persons anywhere in the globe in centering themselves within their respective geographies" (Henry et al 2009: 186).

Silvia Martínez-Falquina starts her essay from the premises that we can and should establish creative dialogues between storytelling and criticism, assuming that theories incorporate narrative patterns and show theories of races in their articulation, and that stories imply and show a familiarity with theory. From these assumptions, MartínezFalquina attempts to engage in a creative dialogue with Gordon Henry"s short story web The Light People (1994) and his autobiographical piece "Entries into the Autobiographical I" (2000) in order to show that the theory of reading offered in them may lead us to transformation and to prove how one author presents Native identities in a way complex enough to unsettle simple positionings we may be tempted to embrace when meeting with the text. Henry"s narratives of the Native body and self let us reconsider the worries of Native history and autobiography in such a way that both story and theory illuminate one another. His texts, she explains, "leave[s] us no alternatives except to become active participants in this reading ceremony" (Henry et al 2009: 206).

Following the theme of the trickster, Michael Wilson analyses this character in Gerald Vizenor"s Bearheart: The Heirship Chronicles (1990). Vizenor asserts the continuing value and even necessity of trickster traditions for their teaching not only about indigenous philosophies but also about current theoretical discussions of language and literature. Wilson remarks on the concept of Vizenor"s compassionate trickster who resists theories that create hierarchies between the conscious and the unconscious, encouraging positive manifestations of the unconscious in creativity, play and selfcriticism. With Bearheart, Vizenor creates worlds where theoretical and practical considerations merge into compassionate narratives of caution and possibility. 
Jane P. Haladay"s essay articulates a theory of storytelling that arises in both the structure and content of Jeannette Armstrong"s Whispering in Shadows through the metaphor of indigenous weaving as a cultural practice and creative process. What is significant is the concept of American Indian women writers" consistent utilization of active, culturally specific processes, which often result in a tangible and valued cultural item (weaving a basket, beading regalia, making a quilt) as a way of theorizing both contemporary writing and the continuation of original Native oral traditions. When understood from this perspective, the ways in which these Native women construct their texts demonstrate the visual and/or literary enactments of these weaving, beading, and/or quilting processes. For Haladay, "Amstrong"s story does not remain confined to the flatness of the printed page but, like an emerging basket, takes shapes from the first strand and arises from the page to weave its meaning within the heart and consciousness of every reader" (Henry et al 2009: 254).

The paradoxes of hybridity and the rejection of the notion that Natives are "vanishing communities" are the central topics of the essay which opens the third section. Teresa Gibert examines how Thomas King grounds his stories in personal recollections and contemporary popular culture to later focus on the social realities of today"s Canadian urban centres and reserves. Throughout interviews with the author and the Massey lectures he delivered in 2003-later published as a book under the title of The Truth about Stories: A Native Narrative-she emphasizes how King "blends theory and practice both by speculating on the enormous potential of storytelling and by narrating a considerable number of [woven] stories" (Henry et al 2009: 266). The combination of elements derived from actual existence and history or those from the world of fantasy mixed with magic realism and surrealism, as well as King"s serious concerns within a comic framework, correct widespread misconceptions about Native peoples and their cultures. King believes in the transformative power of his writings, inviting us to do whatever we wish with them. As Gibert remarks, King"s are "public stories for everyone to use freely, albeit always honestly, for listeners and readers are encouraged to share the moral responsibility of storytelling" (Henry et al 2009: 271).

In an essay with wide-raging examples, Nieves Pascual Soler examines the limits between authenticity and inauthenticity through the imposturing strategies of Stansfield Belaney-an English naturalist who adopted an Indian identity under the name of Grey Old until he was discovered. Pascual Soler asserts that "the narrative of colonization has been a narrative of imposture, built on concepts that repressed all qualitative referents," but imposture demands exposure to exist as a promise of truth (Henry et al 2009: 277). Thanks to his books and photographs, Belaney/Grey Old served the purpose of ethnic reconstruction and reinforced the essentialist categories of oppression. His imposturing does not supplant the self because there is nothing so perfectly hidden that is never undetected. In Pilgrims of the Wild (1935) and Tales of an Empty Cabin: Stories of the Early Days in Canada"s North (1936) Belaney believed his own fabrication. Perhaps his failure was his "excess of indigeneity" (279) to show the essence of pure Nativeness through his images. As Pascual Soler concludes, his imposture is that "of not having dispossessed himself of the truth content of himself" (Henry et al 2009: 289). 
The Eagleheart Narratives are scrutinized by Gordon Henry. The book represents Turtle Mountain elder Francis Cree"s (also known as Eagleheart) words, the ceremonies he discusses and the communities and people he speaks of and through. This ethno/bio/cultural/Indian story will serve as a cultural resource, preserving information about cultural and spiritual perspectives that might otherwise be forgotten and, in Henry"s word, as a way "to energize and empower people, in an on-going development of faculties, for understanding themselves, ourselves and others" (Henry et al 2009: $305)$.

In the last essay of this collection, Patrick R. Lebeau shows how memories and experience can serve as a way of interpreting his own poem story "Earth Death." This story, which "became a method to explore [Lebeau"s] own personal history" (Henry et al 2009: 317), offers not only a contextual world of meaning but also a connection to place and politics, which puts into question the concept of intellectual property and creative ownership. Lebeau reckons that the idea of the poem story bridges the oral tradition with the written word, thus manipulating the language and literary forms of the colonizer to tell a Native American story from a Native American perspective to listeners and readers well beyond the Native American community itself.

Stories Through Theories. Theories Through Stories. North American Indian Writing, Storytelling, and Critique is an innovative work which provides evidence for looking at primary Native cultures, authors, and histories as enrichment of Native literature. The editors" objective has clearly been to provide the reader with a collective and miscellaneous review on storytelling and Indian voice, which they have indeed fulfilled, staying true to their commitment to link several disciplines. Thanks to the documentary efforts of the contributors to this appealing collection of essays, it is possible to understand the particulars of searching and understanding cultural encounters as part of "Indian America." All the sections present enlightening and valuable pieces of scholarship that include a high number of bibliographical references. It is doubtlessly an example of well-written academic work that will be a standard for years to come. One does not lack for reasons to celebrate the arrival of this new volume that challenges out roles as intellectual guides until we enter the uncertain territories where writer, listener, reader, and critic interconnect. 
Born under a Million Shadows, by Andrea Busfield. London: Black Swan, 2009.

Reviewed by Bill Phillips

University of Barcelona (Spain)

In April 2009 the publishers Black Swan brought out Andrea Busfield"s first novel, Born Under a Million Shadows. It has since been translated into a number of different languages, including Spanish, Chinese and German and, unusually for a first time author, it is being heavily publicised. In Spain, for example, El Periódico de Catalunya has carried half page advertisements promoting the book, most recently on October $10^{\text {th }}$. Both the advertisements as well as the cover of the novel itself depict a young Afghan boy running with his head over his shoulder, presumably flying a kite. The background is layered in yellow, brown and green, and the title is printed in a shiny brownish gold script resembling unjoined up handwriting. Anyone familiar with Khaled Hosseini"s bestselling novels The Kite Runner (2003) and A Thousand Splendid Suns (2007), both of which have been filmed (The Kite Runner was released in 2007 while A Thousand Splendid Suns is scheduled for release this year) will immediately be alerted. The similarity with the cover of A Thousand Splendid Suns, with its title printed in a shiny brownish script resembling unjoined up handwriting and its picture of a girl walking against a layered background of yellow and brown is clearly no coincidence. Despite Andrea Busfield"s assertion, then, in The Observer, in April of this year that "I don"t think you could find two more different books than The Kite Runner and Born Under a Million Shadows," her publishers clearly disageree: Black Swan are making every possible effort to sell Busfield"s work on the back of Hosseini"s runaway success.

But are the novels comparable? Hosseini"s, written in deceptively accessible prose, are carefully crafted to expose the horrors of life for many Afghans in recent decades from the point of view, mainly, of children. The Kite Runner takes place both in Afghanistan and the USA, though mainly the former, and describes the friendship between two boys of different social class and ethnic origin. A Thousand Splendid Suns, meanwhile, traces the tragic lives of two women, Mariam and Laila, as they struggle to survive under the oppressive political and religious regimes dominating Afghanistan for the last fifty years. Much of the power and authenticity of Hosseini"s narratives would seem to be attributable to the fact that he was born and spent the first twelve years of his life in Afghanistan before the family moved into exile, first in Paris, and then the United States.

Andrea Busfield is a British journalist whose experiences over a three year period in Kabul provided her with the material for her book. Both authors, therefore, have first hand experience of the country, one as a native, the other as a foreign resident and indeed, this is how the novels are focussed. Fawad, the child protagonist of Busfield"s novel, moves into a house occupied by three foreigners: James, a drunken journalist, May an engineer and Georgie who works for an NGO. Busfield says that:

I wanted to show that members of the international community are not just people looking to earn filthy money and not giving a damn about the country. A lot of them are very 
committed, very trustworthy, honourable, fantastic people. They do mix with locals and locals do mix with them and everybody does get on to a certain degree (Observer).

The three expatriates" characters are carefully chosen to demonstrate that, despite the apparent moral weaknesses of the West, Afghanistan is fortunate to have them. James, the drunkard, who introduces Fawad to beer with predictable results, is, despite his unislamic propensity for alcohol, really both a good man and a good journalist: the freedom of the press being, of course, one of the bulwarks of western civilisation and sadly lacking in ideologically totalitarian societies such as Afghanistan. May, as well as being an engineer, is a lesbian, and why not? Except one rather suspects that Busfield is heavy-handedly pointing out that women can be both engineers and lesbians and be perfectly wonderful people proving that if only the Afghans would wake up to this fact they would be much better off. As no doubt they would. Georgie, one of the central characters of the novel, is also a bit of a drinker, and something of a feminist (with an Enid Blytonish boy"s name, just to make sure the reader is aware of her refusal to satisfy traditional gender specific expectations). She is a woman determined to live life under her own terms, just as one can in the West, unlike in Afghanistan, which is very backward in comparison and thus in dire need of enlightened foreigners whose mere presence is justifiable for their freedom-loving ways.

Fawad, of course, is fascinated by these strange yet liberated people and inevitably his contact with them slowly opens his eyes to his own ignorance and prejudices. None of this, however, is the real plot. The novel is really a love story, a romance in the finest Mills and Boon tradition. Georgie, it transpires, is in love with Haji Khan, one of the most powerful and feared men in the land, a man whose "voice was deep and low [which] suited his face which was strong and framed by thick dark hair, a trim black beard and heavy eyebrows" (Busfield 66). In true Byronic style Haji Khan is also described as "the scourge of the Taliban, the son of one of Afghanistan"s most famous Mujahedin, and now one of the country"s biggest drug dealers" (Busfield 85), the latter charge, of course, proving to be false as the story progresses. He too, is in love with Georgie, but their love is doomed: her principles will not allow her to submit to the degradation of being a Muslim wife, while he cannot allow his position to be undermined by marriage to an immoral infidel: "I"m a Godless kafir, Fawad. Khalid"s a Muslim. How is that even possible in today"s Afghanistan?" (Busfield 184) asks Georgie, rhetorically. To be fair to Busfield she recognises the melodramatic nature of the story she has chosen to unfold and there are constant references to Indian and Afghan films and television series. According to Fawad, Haji Khalid "looked like an Afghan film star, and I hated him for it" (Busfield 66) while in a later scene he "walked down from his bedroom looking like he"d just got off a film set" (189). At one point Fawad and his mother specifically compare Georgie"s problems with "the Tulsi soap opera that came from India", a programme which "finished in another explosion of tears and sad music" (Busfield 250). Not, indeed, that the comparison is unfitting. Later on Georgie is courted by doctor Hugo, an Englishman of the old school, who believes it his duty to inform Haji Khalid that he intends to marry Georgie. Khalid is suitably outraged and screams: "You think you"re in love with Georgie? You think? Well, let me tell you 
something: I am Georgie! That woman is my heart; she is locked in my bones, in my teeth, even in my hairs. Every inch of her is me and every inch of her belongs to me," (Busfield 326) before throwing the doctor to the ground. Clearly, before succumbing to Indian soap opera, Busfield has been brought up on a strict diet of nineteenth century romance (not that, as certain Bollywood films demonstrate, there is much difference). "My love for Heathcliff resembles the eternal rocks beneath: a source of little visible delight, but necessary. Nelly, I am Heathcliff! He"s always, always in my mind" (Emily Brontë 82), cries Cathy in Wuthering Heights, revealing the canonical nature of the reading informing Busfield"s writing. And why not? Kate Bush got away with it, after all.

Such a mountain of obstacles to be overcome: how are Georgie and Khalid ever to be united as man and wife? "Do you imagine," Fawad is told, "even if she converted to Islam, that Georgie could live life as the wife of a high Pashtun man, locked behind the walls of her home, unable to go out, unable to see her male friends, unable to work? It would kill her." And as for Khalid, if "he left to live with a foreign woman, how could he ever return and still keep the respect he and his family have earned over all these terrible years? He would have to live in virtual exile, and that would destroy him" (Busfield 230). Marriage then, either abroad or in Afghanistan, would kill them. What could be more romantic? As the book reaches the final pages Khalid"s compound is attacked and Georgie shot. With her life "pouring from her body like a river" (Busfield 370), she selflessly makes a deathbed conversion to Islam at the hysterical behest of Fawad, who believes she will surely otherwise spend eternity in hell and then "she closed her eyes and Georgie was gone" (Busfield 371). Except she wasn"t. Severely wounded, it is true, indeed so much so that "she couldn"t give him children because her insides were damaged." Yes, reader, she married him "because it was a true love story and they had become famous in the province" (Busfield 381).

My reference to Jane Eyre"s quietly triumphant words "Reader, I married him" (Charlotte Brontë 518) is not idle. Only through Rochester"s mutilation - his loss of sight and use of his left arm, together with Jane"s fortuitous inheritance from her uncle - are they able to overcome the social, economic and gender inequalities that have so far kept them apart. Regardless of his marriage to Bertha Mason, Rochester is simply beyond Jane"s reach. Since Charlotte Brontë "can only imagine marriage as a union with a diminished Samson" (Gilbert \& Gubar 368), in order for Jane to marry Rochester he must be brought down to her level. Similarly, in order for Georgie to marry Khalid, she must be brought down to his. Conveniently converted to Islam through the intercession of the child Fawad, unencumbered by the spiny question of how to bring up their children, and somewhat slowed down, no doubt, by her injuries, Georgie can now submit to the subordinate role of muslim wife even if "she sometimes worked for a company in Kabul - and, even worse than that, men would come to her home who weren"t male relatives" (Busfield 380).

The contrasting representations of Afghans and foreigners is stark in Born Under a Million Shadows. As Busfield says in the Observer article: "I"m still terribly in love with the place; I think it"s fantastic, [...B] ut you can only live there for three years 
before you start to lose your mind." Only by becoming less than the woman she was can Georgie marry Khalid and remain in Afghanistan. The foreigners, despite their carefully selected foibles and eccentricities are the models for a future, more enlightened, happier race of Afghans. The cream of the latter, meanwhile, is a stereotype; the hero of a Bollywood bodice-ripper. To give her her due, Andrea Busfield is right: there is no comparison between Born Under a Million Stones and the novels of Khaled Hosseini, whatever her publishers might want us to think. Economic considerations aside, in inviting comparison between her work and Hosseini"s, they have done her a disservice.

\section{References}

Brontë, C. (1847): Jane Eyre. London: Penguin, 2006.

Brontë, E. (1847): Wuthering Heights. London: Penguin, 1995.

Busfield, Andrea. (2009): Born Under a Million Shadows. London: Black Swan.

Gilbert, S.M. and Gubar, S. (1979): The Madwoman in the Attic. Second Edition. New Haven and London: Yale University Press, 2000.

Hosseini, Khaled. (2003): The Kite Runner. London: Bloomsbury.

- (2007): A Thousand Splendid Suns. London: Bloomsbury.

Smith, David. (2009): “The Upside of Afghanistan” The Observer, London: 19 April. 
Sergio Maruenda-Bataller and Begoña Clavel-Arroitia (eds.) (2011): Multiple Voices in Academic and Professional Discourse: Current Issues in Specialised Language Research, Teaching and New Technologies. Newcastle upon Tyne: Cambridge Scholars Publishing. 673 pages.

Reviewed by Mángeles Ruiz Moneva

University of Zaragoza

Being still a somehow young area of research and teaching -which is shown by the pioneering works of authors such as Trimble (1985), Hutchinson and Waters (1987), or Swales (1990, 1988), and in Spain by Alcaraz (2000); the latter author the authentic alma mater of the IULMA, the Institut Interuniversitari de Llengües Modernes Aplicades, or the Inter-University Institute of Applied Modern Languages, where the work under analysis has to be contextualised-, yet there can be no doubt nowadays that Languages for Specific Purposes (LSP) has become one of the areas of widest interest within linguistic studies.

The work edited by Maruenda-Bataller and Clavel-Arroitia will therefore appeal and be of interest to a wide discourse community of readers. Concretely, the work addresses many different perspectives upon Languages for Academic Purposes (LAP) and also upon Languages for Professional Purposes (LPP). Thus, not only does the work offer insights into ESP -being though a majority-, but also, at the same time, some of the papers contained in it address the use of other languages either for professional or academic purposes - such as Spanish, German, or French, and even some more minority vernacular languages, such as Basque. This work will therefore be of interest to a broad and multifarious audience. This is so not only because of the different languages being approached. Most importantly, the book dwells upon a wide selection of discourse genres, and also upon a broad, though representative, and currently hotly-debated range of topics within academic and professional discourse.

The work is structured into three different parts, devoted, respectively, to "Discourse Analysis in Professional and Academic Genres" -which comprises the first twenty-one chapters of the work-; to "Specialised Translation, Lexicography and Terminology" following with seventeen different chapters-; and finally, a section focusing upon "New Technologies in Teaching and Research within the Field of FLT", which stretches from Chapter Thirty-Eight to the final Fifty-Eight. The authors belong mostly to Spanish Universities, so that another asset of the work is that it shows the invigorating strength of this field of study in Spain. Even so, because of the thoroughness and width of analysis, the work being reviewed will necessarily be regarded as an indispensable tool for the study of LAP and LPP worldwide. The three parts that constitute the work may be said to stand for some of the most outspread tendencies in the study of Languages for Specific Purposes.

Thus, the chapters constituting the first part of the book deal with specialised texts in terms of genres, in so far as these stand for forms of mediation between social situations and the texts that strategically respond to the demands called for by such 
situations (Swales, 2009). In this way, the work is inscribed within some of the most widespread and fruitful tendencies in the study of specialised discourse. Interestingly, different perspectives on genre as a theoretical concept are offered by the editors -like Swales $(2009,2004,1990,1988)$ or Bhatia $(2008,2004,2001,1993)$, in the AngloSaxon context, who tend to stress the social practices leading to the institutionalisation of certain textual formats which are expected to fulfil definite functions; or Parodi (2010a, 2010b), who calls for a multi-dimensional approach to genres, taking into account their social, cognitive and linguistic aspects.

Even though they share this general treatment of genres in professional and academic settings, the aims and perspectives adopted are varied. We shall attempt to group the papers that are included in this section, into the following categories or themes: first, papers dwelling upon academic genres; second, articles coping with different aspects of specialised discourses; third, papers dealing with linguistic and discourse themes; fourth, works tackling with topics connected with learning; fifth, chapters dealing with different aspects of mass media, particularly the press; and sixth, papers showing different facets of multimodality.

Chapters 3 and 5, authored by Gea-Valor and by Carbonell-Olivares, respectively, address two very particular and interesting genres of academic discourse, namely, blurbs of English dictionaries and Ph.D Theses. More concretely, Gea-Valor undertakes a detailed analysis of dictionary blurbs as textual genres, and shows how they are useroriented. In turn, Carbonell-Olivares carries out a contrastive study of acknowledgements in PhdD Theses in English and Spanish, on the basis of Hyland"s model (2004, 2003).

An important number of papers of this first part are devoted to different topics related with specialised discourses. Thus, Pacheco Baldó (ch. 6) addresses aspects of linguistic politeness in intercultural business negotiations, between Spanish and British speakers. Ivorra Pérez (ch. 9) also deals with business intercultural communication between Spanish and English speakers, this time focusing upon a branch of trade of high interest in Alicante, one of the settings where IULMA develops its research, as is the toy industry. Concretely, Ivorra focuses upon the cultural dimension of gender and its impact on the communicative style of web pages of British and Spanish toy enterprises.

Biomedical sciences also have an important space of research in this section. Also within an overall intercultural framework, which has to be seen in the wider context of the current globalisation of scientific investigation, and within some of the most outstanding trends of analysis within academic discourse -as is the research articleOana Maria Carciu (ch. 14) approaches the use of negation in the introductory section of L1 and L2 research articles, where the author must have intended to create the research territory, as described by Swales (1990), and which must have also been intended to foster the diffusion of the investigation undertaken, its visibility and promotion (Bhatia, 2004).

Other fields addressed from interlinguistic, intercultural and translational perspectives are publicity texts in Spanish, French and English (Negro, ch.15), the 
acquisition of communicative competence in scientific French (Olmo Cazevieille, ch. 16), the use of ICTs in English for international tourism within the European Space of Higher Education (Giménez-Moreno and Montañés-Brunet, ch. 17), or the contribution offered by ICTs to legal language through the analysis of blogs penned by Spanish lawyers (Mariottini, ch. 18).

Some of the papers of this section approach more general linguistic or discourse aspects. This is the case of Robles Sabater (Ch. 11), who, in a contrastive study, deals with certain reformulatory discourse markers in Spanish and in German; or Company Rico (ch. 12), who treats dislocated structures from a threefold perspective of integrated syntactic, discursive and cognitive standpoints.

Another group of chapters in the book are devoted to the analysis of different aspects connected with language learning. Thus, Dolón and Fuster (ch. 1) show how corpus linguistics becomes a fruitful tool in university education to promote the student"s autonomous learning. Carrió Pastor (ch.4) approaches the possible ways in which online materials offer new ways to learn, and also facilitate their implementation in the Higher Education classroom, in an overall collaborative approach to language learning, combined with a content and language integrated learning (CLIL) approach. In another proposal on the impact of "new" ICTs upon the teaching-learning context, conducive to fostering higher motivation among learners, García Sánchez (Ch. 19) presents the GranCaMelbourneLanguagesLearning blog, which is bilingual, and which offers entries connected with learning, teaching, and also language and cultural input. Zabala, San Martín, Lersundi and Elordui (Ch.20) show the progress made with the help of the project GARATERM, which has headed for the construction of corpora in a language such as Basque, which is still undergoing a process of normalization. With a more general approach, and as an application of the objectives pursued by the Common European Framework of Reference (CEFR), Hidalgo Downing and Vela Delfa, in the chapter that closes the second part of the book, (Ch. 21), analyse the impact of intercomprehension approaches to teaching and learning foreign languages, particularly, in Romance languages, as a particular aspect of language learning plurilingual approaches.

Some papers address different aspects of media, in particular, traits reflected in press texts. Concretely, Alonso Belmonte (ch.7) seeks to characterise newspaper editorials across different languages, and analyse their predominant rhetorical functions and roles, as a particular instantiation of argumentative texts. A different focus of interest is adopted by Calle Martínez (ch.8), who studies the current situation concerning the use of English loanwords of the economic and financial fields in Spanish press publications. In a previous chapter, Martínez Lirola (ch. 2) approaches multimodal press texts to analyse the way how immigration is dealt with in Spanish press articles from the perspective of critical discourse analysis (CDA).

Also connected with multimodality, and as the final section of the papers that make up this first part of the book, we shall refer to the chapter authored by LaMantia Massimino (ch. 10), who analyses the effects of multimodal discourse upon advertising; and also to the contribution offered by Acevedo and Gil Salom (ch. 13), which may also 
be inscribed in the field of specialised discourse: thus, these authors argue for the need to approach scientific lectures and plenary lectures from more comprehensive, global perspectives, which analyse not only their verbal manifestations, but also their different semiotic, multimodal forms that make it possible to transmit much more complete and fruitful messages to manifold and diverse audiences.

Part 2 analyses diverse aspects of the fields of specialised translation, lexicography and terminology. An important number of papers in this section provide the reader with a wide, representative sample of the possibilities offered by the application of technologies of information and communication for translation and for teaching (Pastor and Alcina; Ferrer Mora; Lázaro, Bodzer and Comsa; Robinson and Olvera-Lobo). Some of these contributions deal with more general aspects of the applications of new technologies. In turn, others discuss possible didactic uses of such recent resources as virtual platforms or social networks.

Another group of papers of this section of the book focus upon particular branches of knowledge to which English for Specific Purposes has been applied, such as law (Santaemilia Ruiz; Uruburu Colsa), medicine (Jiménez Gutiérrez; Marta, Sánchez and Varela;), commercial, economic and financial texts (Lobato Patricio; Barceló Martínez), tourism (López and Baynat; Sanmartín and González), or fashion (Balteiro). These texts approach translational, didactic or lexical aspects of these different lects or professional varieties.

Some other papers within this second part address more general aspects of this field of specialised translation, lexicography and terminology. Thus, Calvo Rigüal analyses the treatment of specialised lexis in six different bilingual Spanish dictionaries. Edo Marzá sets out to determine the extent up to which lexical variation measures used in corpus linguistics can be helpful for the assessment of the richness and the degree of specialisation of texts. The training and background, as well as the professional practice of the technical writer in Germany is analysed in depth by $\mathrm{M}^{\mathrm{a}}$ Dolores and Antonio Forés López. The training that the translator must receive to work as a technical writer is also addressed by the authors.

Part 3 focuses upon relevant aspects of the impact of information and communication technologies (henceforth, ICTs) upon academic and professional settings, and also upon certain practical developments and applications that they offer language users, teachers, learners and also researchers. It is devoted to the exploration of the roles played by new technologies in teaching and research within the field of FLT.

The papers included in this section are, therefore, representative of the wide range of possible uses offered by "new" technologies. More interestingly, in our view, and at the same time, they show the specific projects that the authors of the contributions have been currently developing with the help of these technologies.

As before, we shall briefly refer to some of the aspects that in our view have been catered for by the different authors, even though these do not reflect the actual structure of the book. Our purpose in doing so is merely to offer the reader a representative sample that illustrates the variety and depth of topics that the book being reviewed 
contains. As a result, the book will be found interesting and worthwhile for a wide variety of potential readers, who may find new perspectives and suggestions in the fields covered by the authors. Therefore, among the aspects tackled with in this section of the book, we may mention the following: first, learning applications of ICTs in the university context: (Gómez Ángel; Argüelles, Sendra, Millán, Blanco and Herradón; López Lorca; Oxbrow and Rodríguez-Juárez); second, applications and implementations of ICTs for meta-reflection on the cognitive and procedural aspects of the teaching/ learning process and learning styles, and also with a view to fostering the learner"s autonomy (Matesanz del Barrio, De Miguel García and López Alonso; Gimeno Sanz, Martínez Sáez, Sevilla Pavón and De Siqueira Rocha;): some authors, like Gimeno et al., have developed specific computer tools aiming at more autonomous, self-monitored forms of learning, which in turn have also enabled them to develop coursework materials; third, Internet sites, digital resources and software available for the development and practice of different skills and digital aspects and content, including the use of social networks as aids in the learning process, both of the English language and of other languages (Pino James; Girón García; Cáceres Würsig); fourth, more specific tools, such as the use of digital portfolios or dossiers for teaching and learning Spanish or English as L2 (Morell Moll and Alesón Carbonell); fifth, help, guidance and resources offered to the different protagonists of the teaching/ learning process, and that promote the autonomy of the learner (Vázquez and Lario; FernándezPampillón, Sierra, Sarasa and Matesanz; Pino James; Cabrejas Peñuelas, Cardona Sanchis; Gimeno Sanz, Martínez Sáez, Sevilla Pavón and De Siqueira Rocha); sixth, the teaching of specialised translation (Durán and Muñoz); the application of ICTs for the teaching of specialised translation (Vitalaru and Lázaro Gutiérrez); seventh, resources for the methodology of the basic skills (Estévez, Antón and Martínez Pelegrín); or eighth, applications for the teaching of literature (Simonson and Montero); and also of linguistic disciplines, such as dialectology (Zaragoza Ninet), or applied linguistics (Taillefer de Haya and Muñoz Luna), and even as a way to bridge the gap between linguistics and literature (Alcantud Díaz).

As was the case with the former sections, the contents dealt with are not restricted to the English language, but some of the authors offer their experience in other languages as well. The papers illustrate the manifold aspects that ICTs have contributed in the teaching-learning process and also in research. Such a wide panorama shows the reader the increasing importance of interdisciplinary approaches. It is also shown that ICTs can be applied to the learning process of traditional skills, thus fostering the learner"s autonomy and self-monitoring production, and also learning in collaborative environments. In doing so, many of the didactic proposals offered by the book will certainly contribute to ways of learning foreign languages that enhance learner"s autonomy, their acquisition of skills and competences, and also to the renewal and paradigm changes in the methodologies employed in the learning and acquisition of foreign languages.

On the whole, and as the underlying thread that endows it with internal coherence, the work may be addressed as an innovative research response that aims to call for the 
new social demands on humanities, so that this branch of knowledge may adequately respond to such needs. One of the programmes designed to accomplish such aims and needs in a most successful manner is precisely the study of professional and academic discourse.

We would like to note that the order of chapters that we have followed in our review does not necessarily correspond in all cases with that in which the book is set out. The work is somehow miscellaneous, but precisely because of this fact, it is likely and bound to be of interest to an important number of readers, whose interests may be as broad and diverse as the book itself results to be. Its target readers may be researchers and practitioners of teaching and translation alike. The authors show mastery of the topics they focus upon, as well as acquaintance and knowledge of the most interesting works on the literature related to each of the topics tackled with. Besides, as we have already commented in several points of this review, the topics dealt with are highly topical and hotly-debated issues. In the end, the work provides the reader with sound evidence of the underlying thesis that, in our view, points at: namely, the need for interdisciplinary research. It also shows substantially that the scope of the humanities may offer adequate and fundamental tools for other branches of knowledge. In this sense, it may help potential readers of these areas to develop skills and abilities and to apply them to different contexts. For these reasons, each of the chapters will surely stimulate new ideas in their readers and will provide them with additional food for thought.

\section{References}

Alcaraz, E. (2000): El inglés profesional y académico. Madrid: Alianza Editorial.

Bhatia, V.K. (1993): Analysing genre: Language use in professional settings. London and New York: Longman.

- (2001): Applied genre analysis: a multi-perspective model. IBÉRICA 3: 3-17. http://www.aelfe.org/documents/text4-Bhatia.pdf [Last accessed: 23/12/2011]

- (2004): Worlds of Written Discourse. A Genre-based View. London: Continuum.

(2008): Genre analysis, ESP and professional practice. English for Specific Purposes 27: $161-174$.

Hutchinson, T. \& Waters, E. (1987): English for Specific Purposes. Cambridge: Cambridge University Press.

Hyland, K. (2003): Dissertation acknowledgements: The anatomy of a Cinderella genre. Written Communication 20 (3): 242-268.

- (2004): Graduates" gratitude: the generic structure of dissertation acknowledgements. Findings of a cross-disciplinary investigation. English for Specific Purposes 23 (3): 303324.

IULMA [Institut Interuniversitari de Llengües Modernes Aplicades] / [Inter-University Institute of Applied Modern Languages]: http://www.iulma.es [Last accessed: 23/12/2011]

Parodi, G., ed. (2010a): Academic and Professional Discourse Genres in Spanish. Pontificia Universidad Católica de Valparaíso. 
(2010b): “Academic and professional genre variation across four disciplines: Exploring the PUCV-2006 corpus of written Spanish." Linguagemem (Dis)curso 10(3): 535-567.

Swales, J. (1988): Episodes in ESP. Hemel-Hempstead: Prentice-Hall International. (1990): Genre Analysis: English in Academic and Research Settings. Cambridge: Cambridge University Press.

(2004): Research Genres: Explorations and Applications. Cambridge: Cambridge University Press.

- (2009): Genre in a Changing World. Perspectives on Writing. Eds. C. Bazerman, A. Bonini, \& D. Figueiredo. Fort Collins, Colorado: The WAC Clearinghouse and Parlor Press.

Trimble, L. (1985): English for Science and Technology. A discourse approach. Cambridge: Cambridge University Press. 
La comunicación escrita en el siglo XXI, Quaderns de Filologia, Estudis Lingüistics Vol. XVI, Nicolás Estévez, José Ramón Gómez and María Carbonell, The University of Valencia, 2011.

Reviewed by Francisca González Arias

The University of Massachusetts, Lowell, USA.

The editors, Nicolás Estévez, José Ramón Gómez and María Carbonell, are to be commended for bringing together a valuable collection of essays on the teaching and learning of writing. Their cogent and thoughtfully documented introduction to the issue offers a helpful guide to navigating the information.

The volume is divided into two parts: the first, relating to the issue"s title, $L a$ comunicación escrita en el siglo XXI, applies diverse approaches: linguistic, pedagogical, and, perhaps most relevant, the role of new digital technology and multimedia formats, including social media. The latter are the focus of the second part, which studies their use in the development of writing on the academic, journalistic, and literary and cultural levels.

In the first part"s initial essay, Alasdair Archibald"s "Tracking Essay Writing Strategies of University students Writing Academic Assignments in English as an L2" follows students" planning, research and revising strategies to effectively challenge the traditional view that writing is a linear process involving a series of four distinct stages: Prewriting, Composing, Rewriting, and Editing.

In "Errores discursivos y estilísticos en la expresión escrita: categorización y valoración," José M. Bustos Gisbert helpfully offers a taxonomy of the four most common types of writing errors, privileging revision of the resulting text over revision during the writing process, while he highlights the importance of developing students" awareness of the need for revising and editing their texts.

"Genre Analysis in the Academic Writing Class: With or Without Corpora?" by Viviana Cortés, offers a timely contribution to WAP (Writing for Academic Purposes) scholarship, revealing that while the writing by students who were provided with electronic corpora, and that of students who were provided with articles in print showed no essential differences, the reaction of the first group to the materials used was much more positive that that of the second.

Krista Jaúregui cogently addresses the process and effects of multimodal environments in the teaching and learning of writing in "La negociación de procesos de escritura a través de la videocomunicación," presenting a case study of the interaction between a student and her tutor at Utrecht University.

Sandra Kies"s "Accomodating generation 1.5 in the 21 st century academy: new approaches to writing pedagogy" is a particularly relevant study that speaks to the realities of today"s global society. It highlights the need for a more inclusive approach to immigrant children in the U.S. who attend locals schools, but who speak another language at home, citing factors of bilingualism, multilinguism, the level of socialization, and identity issues. 
In "La comunicación escrita en la Sociedad del Conocimiento. Formación universitaria y desempeño profesional," Estrella Montolío offers a valuable overview of the role of the university in providing students with the skills necessary to transmit professional knowledge effectively, and points to the growing need to incorporate new media technology and formats, as well as an awareness of the evolvution of new professional genres, into the learning process.

Likewise, in "L"enseyament-aprenentatge de la competència comunicativa escrita com a competència transversal en els currículum TIC de la UOC," Ribera, Campos, Marco-Galindo and Pellicer, citing guidelines of the European Space for Higher Education (ESHE), compellingly highlight the need for universities to include courses to develop students" writing skills, redefining and differentiating these from oral communication, in all academic and professional fields.

Initiating the volume"s second part, Francisco Collado Rodríguez"s "Traumatic Techo-Ideology in Contemporary U.S. Fiction and Film: The Limits of the Human in the Post-human era," reflects on the collapse of the traditional barriers between teaching and learning. His exploration of the intriguing concept of the posthuman in the study of postmodernist American fiction, criticism and film impels students to discover and implement reading in a multimodal way, while at the same time making them aware of their own posthuman condition.

David Estrada"s "Humor per a la lectura a la literatura infantil i juvenil," convincingly promotes the use of children"s literature in the classroom citing the enjoyment it provides through the expression of familiar cultural traditions and human situations.

In "El scriptorium vacío," García Martínez, García-Raffi and Hernández Dobón assert cogently that the incorporation of the visual image into the classroom -overcoming the traditional preference for the written-- will only serve to enhance the communicative skills of students who already possess a highly sophisticated visual culture.

Dolors Palau Sampio"s relevant "Del patchwork electr`onic a la trama digital. El desafiament narratiu," focuses on journalism and the combination of skills needed to apply narrative structures to juxtaposed multimedia fragments in order to enhance the cyber reader"s comprehension.

In "El metadiscurso interpersonal y la persuasión en géneros periodísticos: aplicación a la didáctica de la traducción" Francisca Suau Jiménez also addresses journalistic genres, perceptively noting their suitability for teaching translation because of the particular author-reader relationship inherent to the genre with its focus on informing, entertaining and persuading.

The appendix of abstracts in both English and Spanish or Catalan contributes to the edition"s clarity and usefulness. Composed of thoughtful and detailed studies by national and international experts, this impressive volume published by the University of Valencia is a welcome and significant addition on a global level to the multi-faceted field of writing and communication studies. 
Ifantidou, Elly. 2011. Genres and Pragmatic Understanding. Athens: Patakis Publishers.

Reviewed by Begoña Clavel-Arroitia

University of Valencia-IULMA

Genres and Pragmatic Understanding is an in-depth study of the question of the teachability of the pragmatic skills in the interpretation of several written genres. Ifantidou provides groundbreaking insights into the issue of how pragmatics can be taught and offers a series of practical ideas, manifested in a variety of activities, about the introduction of pragmatic issues in the classroom. Moreover, the author offers useful information with which to assess the level of the acquisition of said competences by the students.

The book explores the key issues in the field that are more directly relevant to teaching such as pragmatic competence, which includes pragmatic ability and pragmatic awareness. Ifantidou also takes on the task of redefining pragmatic competence, looks into the relationship between genres and pragmatic competence and finally explains the notions of pragmatic and metapragmatic awareness. Her theoretical descriptions are then complemented in later chapters by the practical applications of those skills in the English Language classroom. The main point of the book is that pragmatic skills can be taught and tested following the author"s methodological approach.

The book is divided into four parts which are in turn divided into chapters. Part A chapters one to five- introduces the theoretical underpinnings on which the book is based. Part B -chapters six and seven- covers the teaching and evaluation of pragmatic awareness while Part $\mathrm{C}$-chapters eight and nine- delves into the teaching and assessment of metapragmatic awareness. Part D includes definitions and examples of key terms.

In the first chapter, Ifantidou discusses the feasibility of the teaching of pragmatics and outlines the main goal of the book which is to show students how to identify "plausible interpretations" in genre-specific texts and the "interpretation routes employed to retrieve them" (21). She considers that genres such as, for example, abstracts, news reports, book blurbs and academic reviews share linguistic markers. However, they lead to different interpretations due to, on the one hand, reader"s assumptions about the attitude of the author and assumptions concerning, among other things, the sociocultural context in which the text has been created and, on the other, the reader"s "expectations, needs or preferences" (21). In this way reader"s involvement through the employment of metalinguistic and metapragmatic strategies enriches the relatively underdetermined meaning in the text itself to create fully-fledged "pragmatically inferred meaning" (21).

The second chapter in part A consists of a historical overview of the notion of pragmatic competence up to the present moment and serves as the introduction to Ifantidou"s own alternative re-definition of the term. Chapter three is devoted to explaining the relationship between genres and pragmatic competence and showing the 
processes which learners go through when interpreting texts from a pragmatic point of view. Chapter four establishes the theoretical assumptions informing parts $\mathrm{B}$ and $\mathrm{C}$ of the book; in particular, it explores the plausibility of using genre conventions as indexes of both linguistic and pragmatic competence. The closing chapter in Part A describes the academic settings in which the author has put her methodology into practice based on the theoretical foundations mentioned in the first part of the book. More specifically, it draws on material previously collected and used by the author in two genre-based language courses at the Faculty of English Studies in the University of Athens and offers a rich collection of activities that can be easily adapted and implemented in different teaching contexts.

The theories in Part A inform the practical discussion in Part B where the author describes the application of the teaching and assessment of pragmatic awareness. Ifantidou focuses on genre conversion and evaluation of pragmatic awareness as tools for instruction and she also shows how they can improve pragmatic competence. Genre conversion is according to the author:

a highly complex, and quite demanding task. It is the shift of genre perspective to serve new needs, preferences, expectations, background knowledge or reader/hearer abilities that make it so. In this sense, genre conversion incurs shifting the context (readership, time, place, contextual assumptions), and the linguistic encoding that can best convey the intended meaning (75).

In chapters 6 and 7 the author offers numerous examples of practical activities that she has designed and applied in the testing of pragmatic awareness as it is defined in earlier chapters. By means of various examples of pairs of related genres, such as book blurbs and abstracts, newspaper headlines and research article titles, abstracts and news reports, research articles and magazine articles, and so on, the main features and structures of different genres are defined and carefully contrasted. These are followed by practical activities and the ways in which they are assessed so as to illustrate the practical application of this methodology in the classroom. In order to provide proof of the applicability of her approach the author not only includes actual examples of the type of activity that she proposes, but also supplies the reader with authentic results and outcomes from the activities her students are involved in. As additional pedagogical material, the reader is provided with illustrative tables where the main traits that define each pair of genre types are shown.

Part $\mathrm{C}$ focuses on the practical application of the teaching and assessment of metapragmatic awareness according to Ifantidou"s own definition in the theoretical section. One of the most important aspects of this section is given in chapter eight. The author puts forward a definition of metapragmatic awareness that includes a number of assumptions that are not considered by standard L2 frameworks. In chapter nine the author offers coursework material with the objective of showing how learners can become metapragmatically aware of differences between a series of genres. She also supplies assessment material in order to show how learners can carry out tasks related to metapragmatic awareness skills at different levels of performance. To this end she 
employs the outline and table of contents genres in addition to the summary and the academic review. In this section we are again given working definitions of the different genres analysed and practical illustrations of authentic student production such as their answers to the activities they are asked to carry out. This is accompanied by comments by the teacher/author. The approach that the author employs helps the reader to grasp more fully the potential usefulness of the exercises provided in the book.

Finally, Part D consists of a list of key linguistic terms which are clearly defined and very skillfully exemplified so that readers (both teachers and students) can reach a perfect understanding of some of the basic notions related to Systemic Functional Grammar, Relevance Theory, Speech Act Pragmatics, etc., all of which are necessary in order to correctly apply the genre approach proposed in the book.

In my view, this book serves, above all else, as a tool to introduce the teaching of pragmatic skills in the English Language classroom and an assessment tool that can be used to test if students have correctly acquired those skills or not. Ifantidou"s book is well worth reading as it offers up-to-date insights on the teaching of Pragmatics from a theoretical point of view and, at the same time, it provides a specific methodological approach that has already been thoroughly tested on the author"s own students.

For anyone who is interested in Second Language Acquisition in general and in the teaching of Pragmatics in particular, this book is essential both as a guide to the fundamental aspects related to the teaching of pragmatic skills from a theoretical perspective and as a pedagogical model with practical applications. On a personal level I found it extremely insightful as the teachability of pragmatic skills is a question that is of interest to many teachers. Like Ifantidou, I also support the thesis that pragmatic skills need to be introduced in the English Language classroom and that students should be offered the right tools to be able to grasp the pragmatic and metapragmatic meanings conveyed by language.

Previous research has also captured the importance of pragmatic skills in the teaching of English (See Cohen and Ishihara, 2009; Rose and Kasper, 2001; Holmes and Brown, 1987; Myers-Scotton and Bernstein, 1988 and Rose, 1994 among others), but this book places special emphasis on the practical implementation of those skills and offers ways to evaluate them. Moreover, the wealth of resources and ideas presented in this volume is comprehensive and will benefit both teachers and students alike.

The author describes how she has used her approach in two university courses: Academic Discourse and Genres in English. This begs the question of whether the genre-driven approach is only appropriate at the tertiary level. Although Ifantidou does not bring up this issue in her book it would be interesting to consider whether teachers in general English classes and ESP courses at university level or general English classes in secondary education should try to start introducing these skills. One of the greatest problems in the English Language classroom at whatever level is that time is always in short supply. If a teacher decides to attempt to raise awareness of the pragmatic dimension of language, that would leave less time to teach grammar, vocabulary, etc. and so it would have to be proved that such a change of focus is worthwhile. In this 
sense, it would have been interesting if Ifantidou had included information on whether her own students found the inclusion of pragmatic and metapragmatic skills useful. Of course, the materials the author teaches are for students whose main interest is reading and writing. It remains to be seen whether her approach could be applied to listening and speaking, and, more interestingly, to the teaching of spoken interaction as envisaged in the Common European Framework of Reference for Languages.

In sum, Ifantidou offers convincing reasons to at least seriously take into consideration the introduction of an awareness of pragmatic/metapragmatic issues in the teaching/learning of English. However, we are still in need of more studies that look into the acquisition of pragmatic skills by students, and how these might be successfully integrated in the English classroom at various levels. The teaching of pragmatic skills has been dealt with previously but not with the attention it deserves. What is needed is more empirical evidence to gauge the appropriateness of its implementation in the classroom.

\section{References}

Cohen, A. D. and N. Ishihara. 2009. "New insights into teaching pragmatics in the ESL/EFL classroom”. Paper presented at the 43rd Annual TESOL Convention, Denver, CO, March 2009.

Holmes, J. and D. F. Brown. 1987. "Teachers and students learning about compliments", TESOL Quarterly, 21, 523-546.

Ifantidou, Elly. 2011. Genres and Pragmatic understanding. Athens: Patakis Publishers.

Mulholland, J. (1999): "E-mail: Uses, issues and problems in an institutional setting". In Bargiela-Chiappini, F. and C. Nickerson (eds.), Writing business: Genres, media and language. London: Longman, 57-84.

Myers-Scotton, C. and J. Bernstein. 1988. "Natural conversation as a model for textbook dialogue", Applied Linguistics, 9, 372-384.

Rose, K. 1994. "Pragmatic consciousness-raising in an EFL context". In Bouton L.F. and Y. Kachru (eds.): Pragmatics and language learning monograph series. Urbana, IL: University of Illinois at Urbana-Champaign, vol.5, 52-63.

Rose, K and G. Kasper. 2001. Pragmatics in language teaching. Cambridge: Cambridge University Press. 